\title{
Response of lung epithelial cells to inflammatory stimuli following exposure to the active form of vitamin D
}

\author{
R. Norton ${ }^{1}$, D. W. Sexton ${ }^{2}$, I. M. Clark ${ }^{2}$, A. M. Wilson ${ }^{2}$, D. A. Hughes ${ }^{3}$ and M. A. O'Connell ${ }^{1}$ \\ ${ }^{1}$ School of Pharmacy, University of East Anglia, Norwich NR4 7TJ, UK, ${ }^{2}$ Biomedical Research Centre, University of \\ East Anglia, Norwich NR4 7TJ, UK and ${ }^{3}$ Research Consultant, Wymondham, Norfolk NR18 OSJ, UK
}

\begin{abstract}
The active form of vitamin $\mathrm{D}\left(1,25(\mathrm{OH})_{2} \mathrm{D}_{3}\right)$ is now of huge interest to the scientific community with numerous beneficial effects beyond $\mathrm{Ca}$ homoeostasis and rickets. Inflammation plays a central role in the pathogenesis of numerous pulmonary diseases and recent evidence suggests vitamin D exerts immunomodulatory effects in the lung. Serum concentrations of inactive $25(\mathrm{OH}) \mathrm{D}_{3}$ have been shown to directly

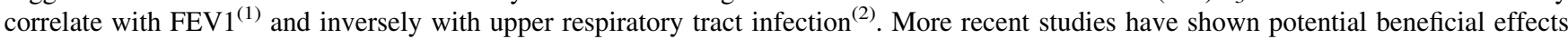
of high dose vitamin D improving treatment for some tuberculosis patients ${ }^{(3)}$. It is clear from this evidence that vitamin D may play an important role in the lung, but due to the low levels of vitamin D available from the diet, it is unlikely that levels of vitamin D required to be of benefit are achievable through diet alone. However, on a cellular level, respiratory epithelial cells have been shown to be capable of activating vitamin $\mathrm{D}^{(4)}$ but as yet it is unknown what concentrations of active vitamin $\mathrm{D}$ can be achieved locally given sufficient serum concentrations of $25(\mathrm{OH}) \mathrm{D}_{3}$. Vitamin D inadequacy is a global problem, especially among elderly patients ${ }^{(5)}$ and with an ever increasing ageing population and lifestyles that reduce exposure to sunlight, it is crucial to identify mechanisms by which vitamin $\mathrm{D}$ improves function and to identify optimal levels. In this study, the effects of $1,25(\mathrm{OH})_{2} \mathrm{D}_{3}$ on pro-inflammatory mediator production were investigated in primary human small airway epithelial cells (SAEC). Cells were incubated with $100 \mathrm{nM} 1,25(\mathrm{OH})_{2} \mathrm{D}_{3}$ for up to $48 \mathrm{~h}$ and the effects on basal mRNA expression of cytokines (IL-1 $\beta$, IL-6, IL-8, TNF $\alpha$, IL-10 and IL-12p70) were investigated using qRT-PCR. $1,25(\mathrm{OH})_{2} \mathrm{D}_{3}$ treatment significantly reduced the expression of IL-6 mRNA from just $1 \mathrm{~h}$ of treatment (results at least in triplicate, one way ANOVA, $P<0.001)$, but had no effect on basal mRNA of the other cytokines. IL-10 and IL-12p70 mRNA and protein were below the limit of detection. Both $10 \mathrm{ng} / \mathrm{ml}$ TNF $\alpha$ and $10 \mu \mathrm{g} / \mathrm{ml}$ lipopolysaccharide (LPS)-induced expression of IL-1 $\beta$, IL-6, IL-8 and TNF $\alpha$

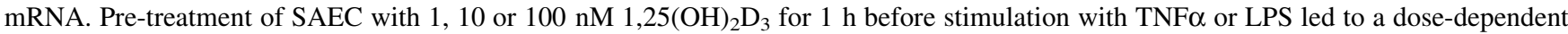
reduction of IL- 6 mRNA induction that was significant at $100 \mathrm{nM}$ with TNF $\alpha$ treatment (results at least in triplicate, $t$ test, $P<0.05$ ). Induction of IL-6 protein expression by TNF $\alpha$ was significantly reduced by $1 \mathrm{~h}$ pre-incubation with $100 \mathrm{nM} 1,25(\mathrm{OH})_{2} \mathrm{D}_{3}$ as assessed by flow cytometry (results in triplicate, one way ANOVA, $P<0.01$ ).

IL-6 is a key cytokine involved in the initiation and extension of the inflammatory response both locally and systemically in lung diseases. This data suggests that vitamin D may be of benefit in reducing IL-6 production by primary human small airway epithelial cells. More research is required into further effects and the mechanism of action of vitamin D on lung epithelium, to determine potential benefits for preventing or treating lung diseases and to define optimum levels.
\end{abstract}

This work was supported by a Norwich Research Park studentship and funding from the Nutricia Research Foundation.

1. Black PN \& Scragg R (2005) Chest 128, 3792-3798.

2. Ginde AA, Mansbach JM \& Camargo CA (2009) Arch Intern Med 169, 384-390.

3. Martineau AR, Timms PM, Bothamley GH et al. (2011) Lancet 377, 242-250.

4. Hansdottir S, Monick MM, Hinde SL et al. (2008) J Immunol 181, 7090-7099.

5. Holick MF (2006) Mayo Clin Proc 81, 353-373. 